\title{
An epidemiological study of haemagglutination in hepatitis
}

\author{
JAMES R. MCARTHUR AND NUALA CROWLEY \\ From the United States Naval Support Activity Medical Department \\ and the Royal Free Hospital Medical School, London
}

SYNOPSIS An epidemiological study of 36 U.S. Marines living in a barracks and exposed to infectious hepatitis was made, and the ability of their sera to agglutinate day-old chick erythrocytes was found to be abnormally high in $52.8 \%$ of the group. The other groups of American Servicemen similarly exposed showed no such deviation from the normally expected incidence of raised titres. An unexplained, abnormally high incidence of raised titres was found in several control groups. The titres appeared to be unaffected to any significant degree by gamma globulin prophylaxis or yellow fever immunization.

The development of a reliable serological test for infectious hepatitis continues to be elusive. Should such a test be evolved which can meet the statistical criteria required for a satisfactory screening procedure, a considerable advance in clinical pathology will have been made. Reviews and evaluations of various methods have been made by MacCallum, McFarlan, Miles, Pollock, and Wilson (1951), Rubin, Kemp, and Bennett (1957), Hoyt and Morrison (1958), Morrison and Hoyt (1957), Morrison, St. Clair, Hoyt, and Stevens (1958), Havens (1958, 1960), McCollum, Bech, Isaacson, and Riordan (1959), Mantila (1960), Jennings and Hindmarsh (1960), and Morris and Nakamura (1960). This paper reports a study of a group of 36 U.S. Marines living in a barracks who were exposed to infectious hepatitis. Serological testing was begun five months after exposure when the group was suspected of being a source of blood transfusion hepatitis.

\section{METHODS}

Sera from the exposed men were tested for their ability to agglutinate day-old chick erythrocytes, using the method described by Havens (1958) and positive control sera kindly supplied by Dr. W. Paul Havens, Jr. The results of testing the control sera are described by Turner, Jha, Crowley, and Sherlock (1962).

\section{RESULTS}

Table I shows the results of the first tests on the Received for publication 10 May 1962. group of 36 men (group 1a). Rather surprisingly, it was found that by Havens (1958) criterion of a titre of $1: 80$ or higher $52.8 \%$ of the sera were abnormal. Repeat blood samples taken a week later were retested and the previous results were confirmed. The patients with the raised titres were examined clinically and bromsulphalein retention and isocitric dehydrogenase estimations were made. There was no clinical evidence of infectious hepatitis, and the only abnormalities were isocitric dehydrogenase values of 12 and 18 units in two men. All bromsulphalein determinations were normal. Subsequent follow-up studies have consistently failed to show any clinical evidence of infectious hepatitis. Similar observations have been reported by Havens (1960), Morrison et al. (1958), and Rightsel, Keltsch, Taylor, Boggs, McLean, Capps, and Weiss (1961).

Since this group of men had all received prophylactic gamma globulin after their exposure to infectious hepatitis and had, because of certain current regulations, received yellow fever immunizations within the past six years, suitable control groups were tested to see if either of these prophylaxes might have caused an abnormally high incidence of haemagglutination. The results (groups 4,5 , and 6 ) are summarized in Table I. No significant difference appears to have been demonstrated.

Finally, two other groups of American Servicemen in the United Kingdom who had been exposed to infectious hepatitis were similarly tested. The results (groups 2 and 3 ) are also shown in Table I. 
TABLE I

HAEMAGGLUTINATION TITRES OF AMERICAN SERVICEMEN EXPOSED TO INFECTIOUS HEPATITIS AND OF UNEXPOSED CONTROL GROUPS

\begin{tabular}{|c|c|c|c|c|c|c|c|c|c|c|c|c|c|}
\hline \multirow{3}{*}{ Group } & \multirow{3}{*}{$\begin{array}{c}1 \\
\text { No. in } \\
\text { Group }\end{array}$} & \multirow{2}{*}{\multicolumn{5}{|c|}{$\begin{array}{c}2 \\
\% \text { Subjects with Titres }\end{array}$}} & \multirow{3}{*}{$\begin{array}{l}\%^{3} \\
- \text { Normal } \\
\text { Titres } \\
(<1: 80)\end{array}$} & \multirow{2}{*}{\multicolumn{2}{|c|}{$\%$}} & \multirow{3}{*}{$\begin{array}{l}\text { Living } \\
\text { in } \\
\text { Barracks }\end{array}$} & \multicolumn{2}{|l|}{5} & \multirow{3}{*}{$\begin{array}{l}\text { Sample Taken } \\
\text { Months after } \\
\text { Exposure or } \\
\text { Immunization }\end{array}$} \\
\hline & & & & & & & & & & & Yellow & Gamma & \\
\hline & & $<1: 80$ & $1: 80$ & $1: 160$ & $1: 320$ & $\begin{array}{l}\text { 1:640 or } \\
\text { higher }\end{array}$ & & $\begin{array}{l}\text { Titres } \\
(>1: 80)\end{array}$ & $\begin{array}{l}\text { Infectious } \\
\text { Hepatitis }\end{array}$ & & $\begin{array}{l}\text { Immuniza- } \\
\text { tion }\end{array}$ & $\begin{array}{l}\text { Prophy- } \\
\text { laxis }\end{array}$ & \\
\hline
\end{tabular}

\begin{tabular}{|c|c|c|c|c|c|c|c|c|c|c|c|c|c|}
\hline \multicolumn{14}{|c|}{ Exposed } \\
\hline la & $\begin{array}{l}36 \\
36\end{array}$ & $\begin{array}{l}47 \cdot 2 \\
69 \cdot 4\end{array}$ & $\begin{array}{l}30 \cdot 6 \\
22 \cdot 2\end{array}$ & $\begin{array}{r}16 \cdot 7 \\
5 \cdot 6\end{array}$ & $\begin{array}{l}0 \\
2 \cdot 8\end{array}$ & $\begin{array}{c}5 \cdot 5 \\
0\end{array}$ & $\begin{array}{l}47 \cdot 2 \\
69 \cdot 4\end{array}$ & $\begin{array}{l}52 \cdot 8 \\
30 \cdot 6\end{array}$ & $\begin{array}{l}\text { Yes } \\
\text { Yes }\end{array}$ & $\begin{array}{l}\text { Yes } \\
\text { Yes }\end{array}$ & $\begin{array}{l}\text { Yes } \\
\text { Yes }\end{array}$ & $\begin{array}{l}\text { Yes } \\
\text { Yes }\end{array}$ & $\begin{array}{r}5 \\
11\end{array}$ \\
\hline $2^{1 b}$ & $\begin{array}{l}36 \\
22\end{array}$ & $77 \cdot 3$ & $13 \cdot 6$ & $9 \cdot 1$ & 0 & 0 & $77 \cdot 3$ & $22 \cdot 7$ & Yes & No & No & No & 8 \\
\hline 3 & 28 & $85 \cdot 6$ & $10 \cdot 7$ & $3 \cdot 6$ & 0 & 0 & $85 \cdot 6$ & $14 \cdot 4$ & Yes & Yes & No & No & 2 \\
\hline \multicolumn{14}{|c|}{ Unexposed } \\
\hline 4 & 36 & $69 \cdot 4$ & $11 \cdot 1$ & $8 \cdot 4$ & $11 \cdot 1$ & 0 & $69 \cdot 4$ & $30 \cdot 6$ & No & No & Yes & No & 3 mth. -5 yr. \\
\hline $5 \mathbf{a}$ & 15 & $66 \cdot 7$ & $13 \cdot 3$ & $6 \cdot 7$ & $13 \cdot 3$ & 0 & $66 \cdot 7$ & $33 \cdot 3$ & No & Yes & Yes & No & $\begin{array}{l}\text { Gamma globu- } \\
\text { lin given after } \\
\text { sample }\end{array}$ \\
\hline $5 b$ & 15 & $60 \cdot 0$ & $26 \cdot 0$ & 14 & 0 & 0 & 60 & 40 & No & Yes & Yes & Yes & $6 \mathrm{mth}$. (a) \\
\hline $6 a$ & 16 & $68 \cdot 7$ & 25 & $6 \cdot 3$ & 0 & 0 & $68 \cdot 7$ & $31 \cdot 3$ & No & No & No & No & $\begin{array}{l}\text { Immunization } \\
\text { after sample }\end{array}$ \\
\hline $6 \mathrm{~h}$ & 16 & $68 \cdot 7$ & $18 \cdot 7$ & $12 \cdot 6$ & $\mathbf{0}$ & 0 & $68 \cdot 7$ & $31 \cdot 3$ & No & No & Yes & No & $\begin{array}{l}\text { 3-6 mth. after } \\
\text { immunization }\end{array}$ \\
\hline
\end{tabular}

\section{DISCUSSION}

It can be seen that the experimental results are inconsistent. The initial group studied showed a percentage of abnormal sera well in excess of the normal distribution established by previous studies (Havens, 1958, 1960; McCollum et al., 1959). It will be noted, however, that the control groups would also have to be considered abnormal, even though there is a significant difference between group 1 and these controls. In fact, the men in groups 2 and 3, who had been exposed to hepatitis, were the only subjects whose titres approached the normal distribution.

Finally, it is of interest to note that repeat serum samples, taken from group 1 six months after the first sample, showed a definite shift toward normal haemagglutination titres. (Over $70 \%$ of those with raised values previously showed a fall in titre.) By this time, the distribution of titres compared closely with that of the control groups, particularly in groups $1 \mathrm{~b}$ and 4.

Several possibilities for the varied results exist. First it will be noted that there is a difference in the time of sampling the exposed groups. Unfortunately, this could not be helped. It may be fortuitous that the first sample (group 1), taken five months after exposure, reflected transient titre rises that would not have been present at either two or eight months. However, there were still more abnormal titres in group 1 at 11 months than there were in group 2 at eight months. Secondly, groups 2 and 3 may not have been even subclinically infected by the viruses to which they had been exposed and the test results may be a reflection of this. Certainly the low virulence of the virus of infectious hepatitis, when trans- mitted by any route except by injection, has been established by MacCallum et al. (1951), by Stokes, Berk, Malamut, Drake, Barondess, Bashe, Wolman, Farquhar, Bevan, Drummond, Maycock, Capps, and Bennett (1954) and by Rightsel et al. (1961). Also the men in group 2 were not living in a barracks; they were bandsmen who rehearsed and performed together almost daily and would thus possibly provide a reservoir for oral transmission of the disease. Transmission under somewhat similar circumstances has been described by Tilley (1960). The members of group 3 were all general duty hospital corpsmen or technicians in a military hospital, and it is quite possible that their specialized knowledge resulted in a sufficiently high degree of personal hygiene to prevent infection. Thirdly, it might be suggested that the different test results reflect a difference in virus strain, with one strain being capable of causing haemagglutination, and the other(s) not. Finally, there is a possible explanation for the abnormally high titres found in the control groups. All the men in groups $1,4,5$, and 6 are required by certain regulations to maintain up-to-date immunization for any part of the world and must, therefore, receive more varied and more frequent inoculations than the men in groups 2 and 3 . Hoyt, Morrison, and Levine (1961) found that the ability of hepatitis serum to produce haemagglutination appears to be contained in the gamma glubulin fraction of the serum, and it seems possible that a crossreacting haemagglutination might be present. Such a hypothesis has not yet been investigated. It is clear, however, that before the test under investigation can be accepted as a valuable screening procedure, further refinement and standardization are needed. 
We are grateful to Captain D. A. Young USAF (MC), and Captain D. D. Klink, USAF (MC), who arranged for blood samples to be taken from groups 2 and 3, and to Professor Sheila Sherlock, Dr. F. O. MacCallum, Cdr. R. K. Barton (MC) USN, and Ledr. S. J. Barcay (MC) USN for their helpful suggestions and criticisms. We gratefully acknowledge the valuable technical assistance of Mrs. A. Rae, F.J.M.L.T.

\section{REFERENCES}

Havens, W. P., Jr. (1958). New Engl. J. Med., 259,1202.

$$
\text { , (1960). Arch. intern. Med., 106, } 327 .
$$

Hoyt, R. E., and Morrison, L. M. (1958). Proc. Soc. exp. Biol. (N.Y.), 93, 547.

- , and Levine. M. G. (1961). J. Lab. clin. Med., 58, 104.

Jennings, E. R., and Hindmarsh, C. (1960). Ibid., 55, 519.

Mantila, S. (1960). Ann. Med. exp. Fenn., 38, 243.
MacCallum, F. O., McFarlan, A. M., Miles, J. A. R., Pollock, M. R., and Wilson, C. (1951). Spec. Rep. Ser. med. Res. Coun. (Lond.), No. 273.

McCollum, R. W., Bech, V., Isaacson, P., and Riordan, J. T. (1959). Amer. J. Med., 27, 703.

Morrison, L. M., and Hoyt, R. E. (1957). J. Lab. clin. Med. 49, 774.

-, St. Clair, E. B., Hoyt, R. E., and Stevens, M. R. (1958). Gastroenterology, 35, 478.

Morris, J. A., and Nakamura, K. (1960). J. Lab. clin. Med., 55, 726. Rubin, B. A., Kemp, H. A., and Bennett, H. D. (1957). Science, 126, 1117 .

Rightsel, W. A., Keltsch, R. A., Taylor, A. R., Boggs, J. D., McLean, I. W.. Jr. (Pt. 1); and Boggs, J. D., Capps, R. B., Weiss, C. F., and McLean, I. W., Jr. (Pt. 2, on p. 678) (1961). J. Amer. med. Ass., 177, 671.

Stokes, J., Jr., Berk, J. E., Malamut, L. L., Drake, M.E., Barondess, J. A., Bashe, W. J., Wolman, I. J., Farquhar, J. D., Bevan, B., Drummond, R. J., Maycock, W. d'A., Capps, R. B., and Bennett, A. M. (1954). Ibid., 154, 1059.

Tilley, J. H., MacDonald (1960). Brit. med. J., 2, 1354.

Turner, P., Jha, V. N., Crowley, N., and Sherlock, S. (1962). J. clin. Path., 15, 491. 